\section{Research Square}

Preprints are preliminary reports that have not undergone peer review. They should not be considered conclusive, used to inform clinical practice, or referenced by the media as validated information.

\title{
Assessment of Gut Bacteria Profile and Antibiotic Resistance Pattern Among Psychotropic Drug Users as Compared With Apparently Healthy Controls: Comparative Cross-sectional Study
}

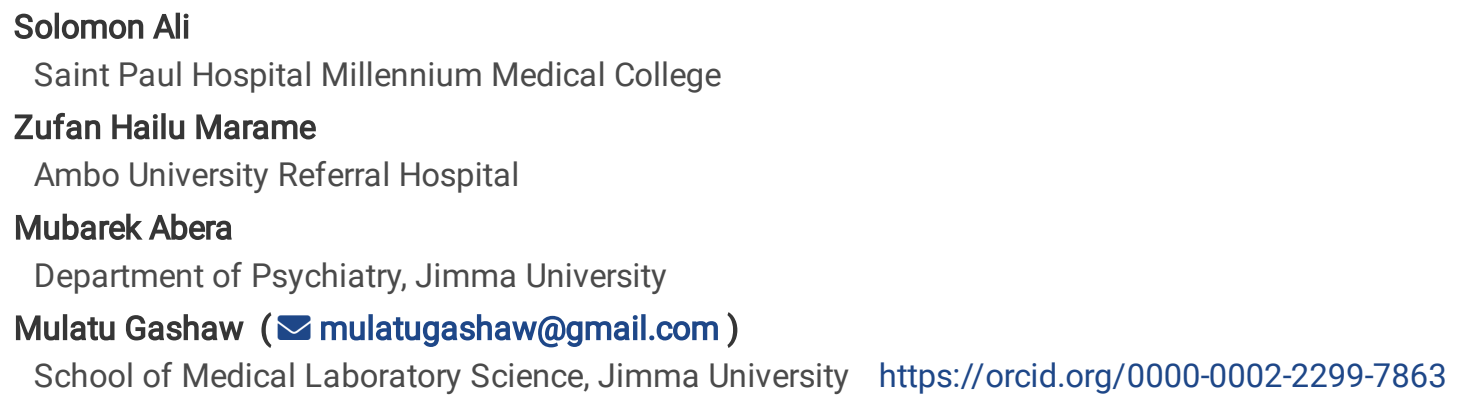

Research

Keywords: Antibiotic drug resistance, psychotropic drugs, gut bacteria

Posted Date: October 28th, 2020

DOI: https://doi.org/10.21203/rs.3.rs-96883/v1

License: @ (1) This work is licensed under a Creative Commons Attribution 4.0 International License. Read Full License 


\section{Abstract}

Introduction: In the $21^{\text {st }}$ century, antibiotic resistance is becoming one of the major global public health threats. Several complex factors are associated with the emergence and spread of antibiotic resistance. Emerging evidences are indicating that drugs used for chronic illness conditions might have a contribution for antibiotic resistance either through drug-drug interactions or metabolism of the drugs by gut microbiota.

Objective: The aim of this study was to compare the bacteria profile and resistance patterns of gut bacteria isolated from participants using psychotropic drugs and apparently healthy controls.

Methods: Socio demographic data were collected from patients using psychotropic medications and apparently healthy persons. Clinical data was collected from patient records. Stool samples were collected from 107 patients using psychotropic medications and 107 apparently healthy controls. Gut bacteria flora were isolated as per recommended bacteria culture isolation and identification methods. Antibiotic susceptibility test was done using the disk diffusion method and Mast disks were used to identify extendedspectrum betalactamase (ESBL) and/or AmpC producing isolates.

Result: A total of 245 bacterial isolates were isolated and identified. From these 124 (50.6\%) bacteria were isolated from patients using Psychotropic medications. There was no bacteria profile difference between the two groups. Escherichia coli was the prevalent [100(80.6\%) and 102 (84.3\%)] bacteria isolated from patients using psychotropic medications and apparently healthy controls, respectively. Escherichia coli isolated from patients using psychotropic medications showed significantly higher resistance against tested amoxicillin-clavulanic acid, cephalosporin $\left(2^{\text {nd }}, 3^{\text {rd }}, 4^{\text {th }}\right.$ generations), Meropenem, ciprofloxacin and Tetracycline. The odds of isolating ESBL producing Enterobacteriaceae [(OR=2.3, 95\% C.I: (1.4-4.0)] and MDR [OR=5.4, 95\% C.I:(1.5-29.8)] was higher on patients using psychotropic medications.

Conclusion: The observed antibiotic resistance pattern of bacteria isolated from guts of patients using psychotropic medications was very high. The magnitude of antibiotic resistance is more pronounced among E.coli isolates.

\section{Introduction}

Emergence and spread of antibiotic resistance are a long standing universal public health problem in the past few decades[1, 2]. Antibiotic resistant in gram-negative bacteria, particularly in coliform opportunistic Enterobacteriaceae are a priority global public health concern[3,4]. These group of bacteria reside in the human gut and have already acquired resistance against most beta lactam antibiotics including 3rd generation cephalosporins and carbapenem antibiotics and they can be the source of drug resistance for other pathogenic microbes[5].

The human gut contains a tightly populated microbial ecosystem that provides ample opportunities for horizontal transfer of genetic materials like antibiotic resistant genes [6] or colonization with MDR bacteria [7]. Various internal and external factors such as age, mode of delivery, environment, diet, genetics and immune responses, prebiotics, probiotics, antibiotics, and non-antibiotic medications can affect the composition and potentially disrupt the ecological balance of the gut microbiota $[8,9]$.

Though, non-antibiotic drugs are developed to treat non-infectious disease, they might have an effect against bacteria. A number of non-antibiotic drugs such as anti-inflammatory drugs, calcium channel blockers, and antidepressants have been reported to exhibit some bactericidal or bacteriostatic activity [10]. For example, the antidepressant Fluoxetine induces multiple antibiotics resistance in Escherichia coli via reactive oxygen species (ROS)-mediated mutagenesis [11]. Thus fluoxetine may play a crucial role in the spread of drug resistance in a community because commensal bacteria serve as the reservoir of antibiotic resistance genes and resistance to a more virulent organism [12]. Other non-antibiotic medications like antipsychotics inhibits the growth of at least one strain of bacteria commonly found in the gut of healthy humans [9].

The current knowledge on the association between non-antibiotic medication usage with gut bacteria profile and resistance pattern is not conclusive given that most of the evidences are reported from high income settings. Therefore, this study aimed to compare the gut bacteria profile and antibiotic resistance pattern of opportunistic coliforms isolated from psychotropic drug users and non-users at low resource settings, Jimma Medical Center, Ethiopia. 


\section{Methods}

\section{Design and Settings}

A comparative cross-sectional study was carried out from March to June 2019 at Jimma medical center (JMC) psychiatric clinic. In the setting, a total of 750 psychiatric patients have regular follow-up visit to the clinic every month. Currently, the clinic has more than 60 inpatient beds for general adult and child psychiatric patients and substance detoxification treatment [13].

\section{Subjects}

Group A: are psychiatry patients who were admitted or had follow up at JMC psychiatry clinic and taking single or combined psychotropic drugs from antipsychotics, antidepressants, or mood stabilizers medications during the study period. Group B: are some volunteer postgraduate students or patient companions from medical outpatient department (OPD) in JMC who had never been on psychotropic drugs and also who did not take antibiotic drugs with in the last six months of the data collection date and whose age and sex were matched with group A.

\section{Sample size}

The sample size was calculated by using EPI- INFO version 7 using the following assumptions. Since there were no similar studies conducted on this specific research topic so far, by considering psychotropic drug use as an exposure variable, it was decided to take $50 \%$ of exposure in both groups. In addition $95 \% \mathrm{Cl}, 80 \%$ power and $1: 1$ ratio was taken. Finally, the sample size includes a total of 107 psychiatry patients and 107 apparently healthy controls. Consecutive sampling technique was employed to include study participants who met the inclusion criteria.

\section{Data collection}

\section{Background data}

Pre-designed and semi-structured questionnaire was used to collect socio-demographic characteristics. The clinical information for group A participants was collected from patient records.

\section{Laboratory data}

Five-gram fecal samples were collected in a sterile wide-mouth screw-capped container and then inoculated on MacConkey agar (Oxoid, Ltd., UK). After overnight incubation at $35-37^{\circ} \mathrm{C}$, suspected colonies on MacConkey agar plates were further identified and confirmed by the pattern of biochemical test using oxidase, indole, and BD BBL crystal Enteric/Non-fermenter identification system (BD, USA) [14].

\section{Antimicrobial Susceptibility Testing}

Antimicrobial susceptibility testing of the isolates were performed using the Kirby-Bauer disk diffusion technique against to the following antibiotics: Ampicillin $(10 \mu \mathrm{g})$, Tetracycline $(30 \mu \mathrm{g})$, Chloramphenicol $(30 \mu \mathrm{g})$, Ciprofloxacin $(5 \mu \mathrm{g})$, TrimethprimSulphamethazole $(25 \mu \mathrm{g})$, Gentamycin $(10 \mu \mathrm{g})$, Ceftriaxone $(30 \mu \mathrm{g})$, Cefotaxime $(30 \mu \mathrm{g})$, Ceftazidime $(10 \mu \mathrm{g})$, Cefepime(30 $\mu \mathrm{g})$, Ampicillin-sulbactam $(20 \mu \mathrm{g})$, Amoxicillin-clavulanic acid $(30 \mu \mathrm{g})$, Cefuroxime $(30 \mu \mathrm{g})$, and Meropenem $(10 \mu \mathrm{g})$. Then, the plate was incubated at $35-37^{\circ} \mathrm{C}$ for $18-24$ hours, and the results were interpreted according to CLSI [15].

\section{ESBL and/or AmpC detection:}

The presence of an ESBL and/or AmpC was determined with Cefpodoxime $(10 \mu \mathrm{g})$, Cefotaxime $(30 \mu \mathrm{g})$, Cefepime $(30 \mu \mathrm{g})$ and Ceftazidime $(30 \mu \mathrm{g})$ containing antibiotic discs (Mast Group Itd, UK) by disc diffusion confirmation test. Finally, zones of inhibition were read and recorded on excel sheet and transported to Mast group ESBL/AmpC and CARBA plus calculator spreadsheet and reported as negative or positive for ESBL or/and AmpC.

\section{Quality control}

To standardize the inoculums density of bacterial suspension for the susceptibility test, a $0.5 \mathrm{McF}$ arland standard was used.

Susceptible reference strains of American Type Culture Collection (ATCC) E. coli 25922 was used to assure antimicrobial susceptibility 
testing using exactly the same procedure as for the test organisms and the results were only accepted when the inhibition zone of control strain was within the ranges as described by CLSI [15] and K. pneumoniae ATCC 700603 were also used for ESBL detection as a positive control.

\section{Statistical analysis}

The data were entered into Epi data manager version 4.4.1 and exported to statistical package for social science (SPSS) version 21 for statistical analyses. Descriptive statistics for percentages and mean were calculated. Odds ratio and Fisher's exact test were employed to compare the bacteria profile and antibiotic resistance of gut bacteria between group A and Group B participants. P-value $\leq 0.05$ was considered as statistically significant.

\section{Ethical consideration}

This research was approved by Jimma university health institute, institutional review board (IRB). Permission was obtained from the JMC management unit. Written informed consent was obtained from the study participants and /or their guardians. The collected data was kept confidential. The specimens collected from the participants were analyzed only for the intended purposes. The pros and cons of the result was communicated to the study participants.

\section{Result}

\section{Background characteristics}

A total of 107 patients using psychotropic medications and 107 apparently healthy controls were enrolled in the study. The mean age of patients was 30.95 ( $S D \pm 9.6$ ) years, and for healthy controls was $30.59(\mathrm{SD} \pm 8.96)$. Nearly three fourth $80(74.8 \%)$ of the patients and controls were males. Almost half of the patient 54(50.5\%) and $42(39.3 \%)$ of the controls live in urban settings. Of the total patients using psychotropic medications, 57(53.3\%), 28(26.2\%), and 21(19.6\%) had schizophrenia, bipolar disorder, and depression respectively. About $75(70.1 \%)$ of the patients had duration of illness greater than 12 months. Regarding type of drugs, about 54(50.5\%) of patients have been taking anti-psychotics only, 14(13.1\%) mood stabilizers only, 11(10.3\%) anti-depressants only, and $28(26.1 \%)$ took combination therapy of either of the above medications (Fig. 1). A total of $72(67.3 \%)$ patients were used the drug for more than 12 months.

\section{Bacterial profile and antimicrobial resistance patterns of isolates}

From 214 stool samples collected from both groups, 124 and 121 bacteria were isolated from patients and apparently healthy controls respectively. The most frequently isolated bacteria from patients and apparently healthy controls were $E$. coli, which was 100(80.6\%) and $102(84.3 \%)$ respectively (Table 1). Among 100 E. coli isolated from patients, 99(99.0\%) were resistant to tetracycline and ampicillin each and $58(58.0 \%)$ to cefotaxime. On the other hand, among bacteria isolated from control groups, 96(94.1\%), $57(55.9 \%)$ and $50(49.0 \%)$ of E. coli were found to be resistant to ampicillin, tetracycline, and trimethoprim-sulfamethoxazole respectively. Generally, the proportion of resistant isolates of cases were higher than the isolates of controls in all of the tested antibiotics except trimethoprim-sulfamethoxazole (Table 1). 
Table 1

Drug resistance patterns of bacteria isolated from cases and controls to different antibiotics

\begin{tabular}{|c|c|c|c|c|c|c|c|c|c|c|c|c|c|c|c|}
\hline \multicolumn{2}{|c|}{ Isolated bacteria } & \multirow{2}{*}{$\begin{array}{l}\text { AMP } \\
99\end{array}$} & \multirow{2}{*}{$\begin{array}{l}\text { CN } \\
1\end{array}$} & \multirow{2}{*}{$\begin{array}{l}\text { AMC } \\
17\end{array}$} & \multirow{2}{*}{$\begin{array}{l}\text { CXM } \\
19\end{array}$} & \multirow{2}{*}{$\begin{array}{l}\text { CRO } \\
18\end{array}$} & \multirow{2}{*}{$\begin{array}{l}\text { CAZ } \\
18\end{array}$} & \multirow{2}{*}{$\begin{array}{l}\text { FEP } \\
26\end{array}$} & \multirow{2}{*}{$\begin{array}{l}\text { CTX } \\
58\end{array}$} & \multirow{2}{*}{$\begin{array}{l}\text { MRP } \\
21\end{array}$} & \multirow{2}{*}{$\begin{array}{l}\text { CIP } \\
17\end{array}$} & \multirow{2}{*}{$\begin{array}{l}\text { SXT } \\
36\end{array}$} & \multirow{2}{*}{$\begin{array}{l}\mathrm{CHL} \\
8\end{array}$} & \multirow{2}{*}{$\begin{array}{l}\text { AMS } \\
23\end{array}$} & \multirow{2}{*}{$\begin{array}{l}\text { TE } \\
99\end{array}$} \\
\hline E. coli & $\begin{array}{l}\text { Group } \\
A(n= \\
100)\end{array}$ & & & & & & & & & & & & & & \\
\hline & $\begin{array}{l}\text { Group } \\
B(n= \\
102)\end{array}$ & 96 & 0 & 5 & 8 & 6 & 10 & 6 & 17 & 5 & 5 & 50 & 7 & 25 & 57 \\
\hline \multirow[t]{2}{*}{$\begin{array}{l}\text { Klebsiella } \\
\text { spp. }\end{array}$} & $\begin{array}{l}\text { Group } \\
\text { A }(n= \\
8)\end{array}$ & 8 & 0 & 0 & 0 & 0 & 1 & 1 & 6 & 2 & 1 & 4 & 0 & 1 & 8 \\
\hline & $\begin{array}{l}\text { Group } \\
B(n= \\
9)\end{array}$ & 9 & 0 & 0 & 0 & 0 & 0 & 0 & 0 & 0 & 2 & 6 & 1 & 1 & 7 \\
\hline \multirow[t]{2}{*}{$\begin{array}{l}\text { Enterobacter } \\
\text { spp. }\end{array}$} & $\begin{array}{l}\text { Group } \\
A(n= \\
6)\end{array}$ & 6 & 0 & 0 & 1 & 1 & 1 & 1 & 2 & 0 & 1 & 1 & 1 & 0 & 6 \\
\hline & $\begin{array}{l}\text { Group } \\
B(n= \\
6)\end{array}$ & 6 & 0 & 0 & 0 & 1 & 0 & 0 & 2 & 0 & 0 & 0 & 0 & 0 & 5 \\
\hline \multirow[t]{2}{*}{$\begin{array}{l}\text { Citrobacter } \\
\text { spp. }\end{array}$} & $\begin{array}{l}\text { Group } \\
A(n= \\
6)\end{array}$ & 6 & 0 & 1 & 2 & 2 & 2 & 3 & 4 & 0 & 2 & 2 & 2 & 4 & 6 \\
\hline & $\begin{array}{l}\text { Group } \\
B(n= \\
3)\end{array}$ & 3 & 0 & 0 & 0 & 0 & 0 & 0 & 0 & 0 & 0 & 2 & 1 & 1 & 1 \\
\hline \multirow[t]{2}{*}{ S. rubidaea } & $\begin{array}{l}\text { Group } \\
A(n= \\
1)\end{array}$ & 1 & 0 & 0 & 0 & 0 & 1 & 0 & 0 & 0 & 0 & 1 & 0 & 1 & 1 \\
\hline & $\begin{array}{l}\text { Group } \\
B(n= \\
1)\end{array}$ & 1 & 0 & 0 & 0 & 0 & 0 & 0 & 0 & 0 & 0 & 1 & 0 & 1 & 1 \\
\hline $\begin{array}{l}P . \\
\text { agglomerans } \\
(n=3)\end{array}$ & $\begin{array}{l}\text { Group } \\
A(n= \\
3)\end{array}$ & 3 & 0 & 1 & 0 & 0 & 0 & 0 & 3 & 0 & 0 & 1 & 0 & 2 & 3 \\
\hline \multirow[t]{2}{*}{$\begin{array}{l}\text { Total }(n= \\
245)\end{array}$} & $\begin{array}{l}\text { Group } \\
A(n= \\
124)\end{array}$ & 123 & 1 & 19 & 30 & 21 & 23 & 31 & 73 & 23 & 21 & 45 & 11 & 31 & 123 \\
\hline & $\begin{array}{l}\text { Group } \\
B(n= \\
121)\end{array}$ & 115 & 0 & 5 & 8 & 7 & 10 & 6 & 19 & 5 & 7 & 59 & 9 & 8 & 71 \\
\hline $\begin{array}{l}\text { Key: AMP = An } \\
\text { Ceftazidime, F } \\
\mathrm{CHL}=\text { Chloran } \\
\text { controls }\end{array}$ & $\begin{array}{l}\text { icillin, C } \\
=\text { Cefe! } \\
\text { nenicol, }\end{array}$ & $\begin{array}{l}=\text { Gen } \\
\text { me, CT } \\
M S=A\end{array}$ & $\begin{array}{l}\text { nyci } \\
=\mathrm{Ce} \\
\text { ipicil }\end{array}$ & $\begin{array}{l}\text { AMC = } \\
\text { taxime } \\
\text { n-sulba }\end{array}$ & $\begin{array}{l}\text { Amoxi } \\
\text { MRP = } \\
\text { tam, T }\end{array}$ & $\begin{array}{l}\text { lin-cla } \\
\text { lerope } \\
=\text { Tetra }\end{array}$ & $\begin{array}{l}\text { lanic } \\
\text { em, Cl } \\
\text { ycline }\end{array}$ & $\begin{array}{l}\text { cid, CX } \\
=\text { Cipr } \\
\text { Group }\end{array}$ & $\begin{array}{l}\text { 1 }=\mathrm{Ce} \\
\text { Ioxac } \\
=\text { Psy }\end{array}$ & $\begin{array}{l}\text { roxime } \\
\text { SXT = } \\
\text { iatry p }\end{array}$ & $\begin{array}{l}\text { CRO } \\
\text { Trime } \\
\text { tients }\end{array}$ & $\begin{array}{l}\text { Ceftria } \\
\text { oprim } \\
\text { Group }\end{array}$ & $\begin{array}{l}\text { one, } \\
\text { ulfam } \\
=A p p\end{array}$ & $\begin{array}{l}z= \\
\text { hoxaz } \\
\text { rently }\end{array}$ & alth \\
\hline
\end{tabular}

Comparison of drug resistance pattern of E. Coli isolated from patients taking Psychotropic drugs with apparently healthy controls

Escherichia coli is the leading bacteria isolated from both group of participants. Comparison of antibiotic resistance pattern of $E$. coli was described in (Table 2). Accordingly, amoxicillin clavulic acid, cefuroxime, ceftriaxone, cefepime, cefotaxime, meropenem, ciprofloxacin, and tetracycline resistance are significantly higher among $E$. coli bacteria isolated from participants taking psychotropic drugs than E. coli bacteria isolated from apparently healthy controls (Table 2). 
Table 2

Comparison of resistance pattern frequency of $E$. coli isolated from patients and controls

\begin{tabular}{|c|c|c|c|c|c|}
\hline Antibiotic & Pattern & $\begin{array}{l}\text { E. coli } \\
\text { (patients) }\end{array}$ & $\begin{array}{l}\text { E. coli } \\
\text { (controls) }\end{array}$ & Chi-square & P-value \\
\hline \multirow[t]{2}{*}{ AMC } & $S$ & 83 & 97 & \multirow[t]{2}{*}{7.62} & \multirow[t]{2}{*}{0.005} \\
\hline & $\mathrm{R}$ & 17 & 5 & & \\
\hline \multirow[t]{2}{*}{ CXM } & $S$ & 81 & 94 & \multirow[t]{2}{*}{5.43} & \multirow[t]{2}{*}{0.020} \\
\hline & $\mathrm{R}$ & 19 & 8 & & \\
\hline \multirow[t]{2}{*}{ CRO } & $S$ & 82 & 96 & \multirow[t]{2}{*}{7.08} & \multirow[t]{2}{*}{0.008} \\
\hline & $\mathrm{R}$ & 18 & 6 & & \\
\hline \multirow[t]{2}{*}{ FEP } & $S$ & 74 & 96 & \multirow[t]{2}{*}{15.33} & \multirow[t]{2}{*}{0.000} \\
\hline & $\mathrm{R}$ & 26 & 6 & & \\
\hline \multirow[t]{2}{*}{ CTX } & $S$ & 42 & 85 & \multirow[t]{2}{*}{36.96} & \multirow[t]{2}{*}{0.000} \\
\hline & $\mathrm{R}$ & 58 & 17 & & \\
\hline \multirow[t]{2}{*}{ MRP } & $S$ & 79 & 97 & \multirow[t]{2}{*}{11.67} & \multirow[t]{2}{*}{0.001} \\
\hline & $\mathrm{R}$ & 21 & 5 & & \\
\hline \multirow[t]{2}{*}{ CIP } & $S$ & 83 & 97 & \multirow[t]{2}{*}{7.62} & \multirow[t]{2}{*}{0.005} \\
\hline & $\mathrm{R}$ & 17 & 5 & & \\
\hline \multirow[t]{2}{*}{ TE } & $S$ & 1 & 45 & 53.38 & 0.000 \\
\hline & $\mathrm{R}$ & 99 & 57 & & \\
\hline Total & & 100 & 102 & & \\
\hline $\begin{array}{l}\text { Key: AMC } \\
\text { Meropenen }\end{array}$ & $\begin{array}{l}\text {-clavulan } \\
\text { ofloxacin }\end{array}$ & $\begin{array}{l}\mathrm{M}=\text { Cefur } \\
\text { cycline } \mathrm{S}\end{array}$ & $\begin{array}{l}\text { Ceftriaxon } \\
\text { e, } \mathrm{R}=\text { Resis }\end{array}$ & epime, CTX & MRP = \\
\hline
\end{tabular}

\section{Multidrug resistance in bacterial isolates}

The overall rate of multidrug resistance (resistant to at least one agent in three or more antimicrobial categories) among bacteria isolated from psychiatry patients were $78(63 \%)$ whereas it accounts $51(42.1 \%)$ among bacteria isolated from apparently healthy controls. The odds of isolating MDR bacteria from patients was higher than healthy controls [OR = 5.4, 95\% C. I:(1.5-29.8)] (Table 3). The majority of MDR bacteria 48(61.5\%) and 29(56.9\%) were isolated from the age category between 25-34 years from patients and healthy controls respectively. More than half $42(53.8 \%)$ of MDR bacteria were isolated from patients who had Schizophrenia, $56(71.8 \%)$ were from patients with duration of illness for more than one year, $41(52.6 \%)$ were from patients who have been taking antipsychotic medications only and 52(66.7\%) were from patients who had used the drug for more than one year.

\section{Proportion of ESBL producing isolates}

Out of the total 124 bacteria isolated from patents, 15(12.1\%) were ESBL producers. Likewise, out of the 100 E. coli bacteria isolated from patients, $13(13 \%)$ were ESBL producers. In comparison, only three $E$. coli bacteria isolated from the healthy controls were ESBL producers. More than half of ESBL producing bacteria 8(53.3\%) were isolated from patients with schizophrenia, having duration of illness greater than 1 year, and treated with antipsychotic drugs only. In this study, the proportion of ESBL producing bacterial isolates were higher in cases than controls (12.1\% vs $2.5 \%)$. The odds of isolating ESBL producing Enterobacteriaceae is higher on patients than healthy controls $(\mathrm{OR}=2.3,95 \%$ C.I: (1.4-4.0) (Table 3$)$. 
Table 2

The association between psychotropic drug use with ESBL producing and MDR bacteria of gut

\begin{tabular}{|lllllll|}
\hline Variables & \multicolumn{2}{l}{ ESBL producer } & Odds Ratio & \multicolumn{2}{l}{ MDR } & \multicolumn{2}{c|}{ Odds Ratio } \\
\cline { 2 - 3 } & Yes & No & & Yes & No & \\
Cases & 15 & 109 & $5.4(1.5-29.8)$ & 78 & 46 & $2.3(1.4-4.0)$ \\
\hline Controls & 3 & 118 & $P \leq 0.003$ & 51 & 70 & $P \leq 0.001$ \\
\hline
\end{tabular}

Key: MDR = resistant to at least one agent in three or more antimicrobial categories, ESBL $=$ extended spectrum beta-lactamases

\section{Discussion}

A total of 245 strains of bacteria were isolated. There is no difference in bacteria profile isolated from patients and healthy controls. The most frequently isolated bacteria from patients and healthy controls were E. coli, followed by Klebsiella and Enterobacter species. This might be due to the close similarity in the age, geographical region, and environment for both groups, which are the possible factors that affect the composition of gut bacteria [16]. The predominance of E. coli and Klebsiella species in this finding was supported by a research done in Nepalese [17].

In this study, it is observed that amoxicillin clavulic acid, cefuroxime, ceftriaxone, cefepime, cefotaxime, meropenem, ciprofloxacin, and tetracycline resistance are more common among $E$. coli isolated from participants taking psychotropic drugs. Conversely there is no statistical difference against ampicillin, gentamycin, ceftazidime, trimethoprim-sulfamethoxazole, chloramphenicol and ampicillinsulbactam. Depicting the mechanism for the observed high resistance of $E$. coli isolated from patients using psychotropic medications is out of the scope of this study. However, one previous evidence has indicated that $E$. coli exposed to fluoxetine increased resistance to tetracycline via the overproduction of reactive oxygen species, which causes mutations in the transcriptional regulator genes that result in the over-expression of the multidrug efflux system and promote antibiotics efflux and decreased outer membrane porin protein to block antibiotics from entering the cell [11]. Furthermore, another study in the Slovak showed high proportion of antibiotic resistance in coliforms isolated from wastewater with high concentration of psychoactive compounds like cotinine, tramadol, methamphetamine and venlafaxine, and compounds[18].

Multidrug resistant (MDR) and extended spectrum beta lactam antibiotic resistance was higher on bacteria isolated from patients using psychotropic drug as compared with isolates from apparently health controls. This inferred that psychotropic drug use might have a direct contribution for the emergence of MDR and ESBL producing gut bacteria in psychotropic medication users. This hypothesis is substantiated by previous study which reported that MDR was observed in commensal bacteria isolated from patients who took psychotropic drug due to the induction of multiple antibiotics resistance genes [11].

Although there is no much evidence about the contribution of psychotropic drugs in the emergence of antibiotic resistance in gut bacteria, the studies done in different parts of the world depicted exposure to the antidepressants like fluoxetine [11, 19], a tricyclic antidepressant (amitriptyline hydrochloride) [20], escitalopram [19] sertraline and paroxetine [21, 22] have been shown to have antimicrobial activity against Gram-positive and Gram-negative bacteria residing in the human gut such as E.coli, L. rhamnosus, Citrobacter and $P$. aeruginosa.

These psychotropic drugs could contribute to drug resistance in different ways. The use of antipsychotic drugs may also cause the bacteria to induce both ESBL and AmpC production which might be due to mutation of genes that encode beta-lactamases enzyme, modifications of the antimicrobial target, activation of efflux mechanisms to extrude the drug and global changes in important metabolic pathways via modulation of regulatory networks [23].

Generally, prolonged antimicrobial effects of psychotropic drugs may cause the emergence of drug resistance in commensal gut bacteria, gut colonization with MDR commensal bacteria could be the source of infections to themselves, their families, other individuals, hospitalized patients, and the community at large [7].

\section{Conclusion}


There is a high antibiotic resistance Enterobacteriaceae among patients using psychotropic medications than health controls. Specifically, E.coli isolated from patients using psychotropic medications showed significantly higher resistance against tested beta lactam and other antibiotics. The magnitude of ESBL producing and MDR bacteria carriage among patients using psychiatric medications were very concerning.

\section{Abbreviations}

ESBL

Extended spectrum betalactamase; JMC:Jimma Medical Center; MDR:Multidrug resistant;

\section{Declarations}

\section{Acknowledgment}

We are gratefully to thank Jimma University for funding this work and data collectors and study participants are highly acknowledged.

\section{Funding}

This project was funded by Jimma University through the Institute of Health, Research and Postgraduate Office.

\section{Availability of data}

The data used in the findings of this study are included in the manuscript.

\section{Authors' contributions}

MG and SA conceived and designed the idea. MG and ZHM participated in data collection, analysis, interpretation, and manuscript writing. MG, SA, ZHM and MA participated in study design, development of instruments, editing and revision of the manuscript. All authors read and approved the final manuscript in its current form.

\section{Ethics approval and consent to participate}

The study was approved by the Institutional Review Board of Institute of Health, Jimma University.

\section{Consent for publication}

Not applicable - This manuscript does not contain any individual person's data.

\section{Competing interests}

All the authors declare that they have no competing interests.

\section{References}

1. Wellington EM, Boxall AB, Cross P, Feil EJ, Gaze WH, Hawkey PM, et al. The role of the natural environment in the emergence of antibiotic resistance in Gram-negative bacteria. The Lancet infectious diseases. 2013;13(2):155-65.

2. Leonard AF, Zhang L, Balfour AJ, Garside R, Hawkey PM, Murray AK, et al. Exposure to and colonisation by antibiotic-resistant E. coli in UK coastal water users: Environmental surveillance, exposure assessment, and epidemiological study (Beach Bum Survey). Environment international. 2018;114:326-33.

3. Han R, Shi Q, Wu S, Yin D, Peng M, Dong D, et al. Dissemination of Carbapenemases (KPC, NDM, OXA-48, IMP, and VIM) Among Carbapenem-Resistant Enterobacteriaceae Isolated From Adult and Children Patients in China. Frontiers in Cellular and Infection Microbiology. 2020;10.

4. Yu X, Zhang M, Zuo J, Shi X, Tang X, Chen L, et al. Evaluation of antibiotic resistant lactose fermentative opportunistic pathogenic Enterobacteriaceae bacteria and blaTEM-2 gene in cephalosporin wastewater and its discharge receiving river. Journal of 
environmental management. 2018;228:458-65.

5. Iseppi R, Di Cerbo A, Messi P, Sabia C. Antibiotic Resistance and Virulence Traits in Vancomycin-Resistant Enterococci (VRE) and Extended-Spectrum $\rrbracket$-Lactamase/AmpC-producing (ESBL/AmpC) Enterobacteriaceae from Humans and Pets. Antibiotics. 2020;9(4):152.

6. Van Schaik W. The human gut resistome. Philosophical Transactions of the Royal Society B: Biological Sciences. 2015;370(1670):20140087.

7. Carlet J. The gut is the epicentre of antibiotic resistance. Antimicrobial resistance and infection control. 2012;1(1):39.

8. Hasan N, Yang H. Factors affecting the composition of the gut microbiota, and its modulation. PeerJ. 2019;7:e7502.

9. Maier L, Pruteanu M, Kuhn M, Zeller G, Telzerow A, Anderson EE, et al. Extensive impact of non-antibiotic drugs on human gut bacteria. Nature. 2018;555(7698):623-8.

10. Cederlund H, Mårdh P-A. Antibacterial activities of non-antibiotic drugs. Journal of Antimicrobial Chemotherapy. 1993;32(3):35565.

11. Jin M, Lu J, Chen Z, Nguyen SH, Mao L, Li J, et al. Antidepressant fluoxetine induces multiple antibiotics resistance in Escherichia coli via ROS-mediated mutagenesis. Environment international. 2018;120:421-30.

12. Oluyege A, Ojo-Bola O, Oludada O. Carriage of antibiotic resistant commensal E. coli in infants below 5 months in Ado-Ekiti. International Journal of Current Microbiology and Applied Sciences. 2015;4:1096-102.

13. Ayalew M, Workicho A, Tesfaye E, Hailesilasie H, Abera M. Burden among caregivers of people with mental illness at Jimma University Medical Center, Southwest Ethiopia: a cross-sectional study. Annals of General Psychiatry. 2019;18(1):10.

14. Cheesbrough M. District laboratory practice in tropical countries, part 2: Cambridge university press; 2006.

15. Clinical, Institute LS. Performance standards for antimicrobial susceptibility testing. Clinical and Laboratory Standards Institute Wayne, PA; 2017.

16. Mueller S, Saunier K, Hanisch C, Norin E, Alm L, Midtvedt T, et al. Differences in fecal microbiota in different European study populations in relation to age, gender, and country: a cross-sectional study. Applied and environmental microbiology. 2006;72(2):1027-33.

17. Maharjan A, Bhetwal A, Shakya S, Satyal D, Shah S, Joshi G, et al. Ugly bugs in healthy guts! Carriage of multidrug-resistant and ESBL-producing commensal Enterobacteriaceae in the intestine of healthy Nepalese adults. Infection and drug resistance. 2018;11:547.

18. Mackulak T, Medvecká E, Staňová AV, Brandeburová P, Grabic R, Golovko O, et al. Boron doped diamond electrode-The elimination of psychoactive drugs and resistant bacteria from wastewater. Vacuum. 2020;171:108957.

19. Cussotto S, Strain CR, Fouhy F, Strain RG, Peterson VL, Clarke G, et al. Differential effects of psychotropic drugs on microbiome composition and gastrointestinal function. Psychopharmacology. 2019;236(5):1671-85.

20. Anurup M, Chandrima S, Jena AK, Soma G, Amalesh S. An investigation on in vitro and in vivo antimicrobial properties of the antidepressant: amitriptyline hydrochloride. Brazilian Journal of Microbiology. 2010;41(3):635-42.

21. Bohnert JA, Szymaniak-Vits M, Schuster S, Kern WV. Efflux inhibition by selective serotonin reuptake inhibitors in Escherichia coli. Journal of antimicrobial chemotherapy. 2011;66(9):2057-60.

22. Munoz-Bellido J, Munoz-Criado S, Garcla-Rodrıguez J. Antimicrobial activity of psychotropic drugs: selective serotonin reuptake inhibitors. International journal of antimicrobial agents. 2000;14(3):177-80.

23. Munita JM, Arias CA. Mechanisms of antibiotic resistance. Virulence mechanisms of bacterial pathogens. 2016:481-511.

\section{Figures}




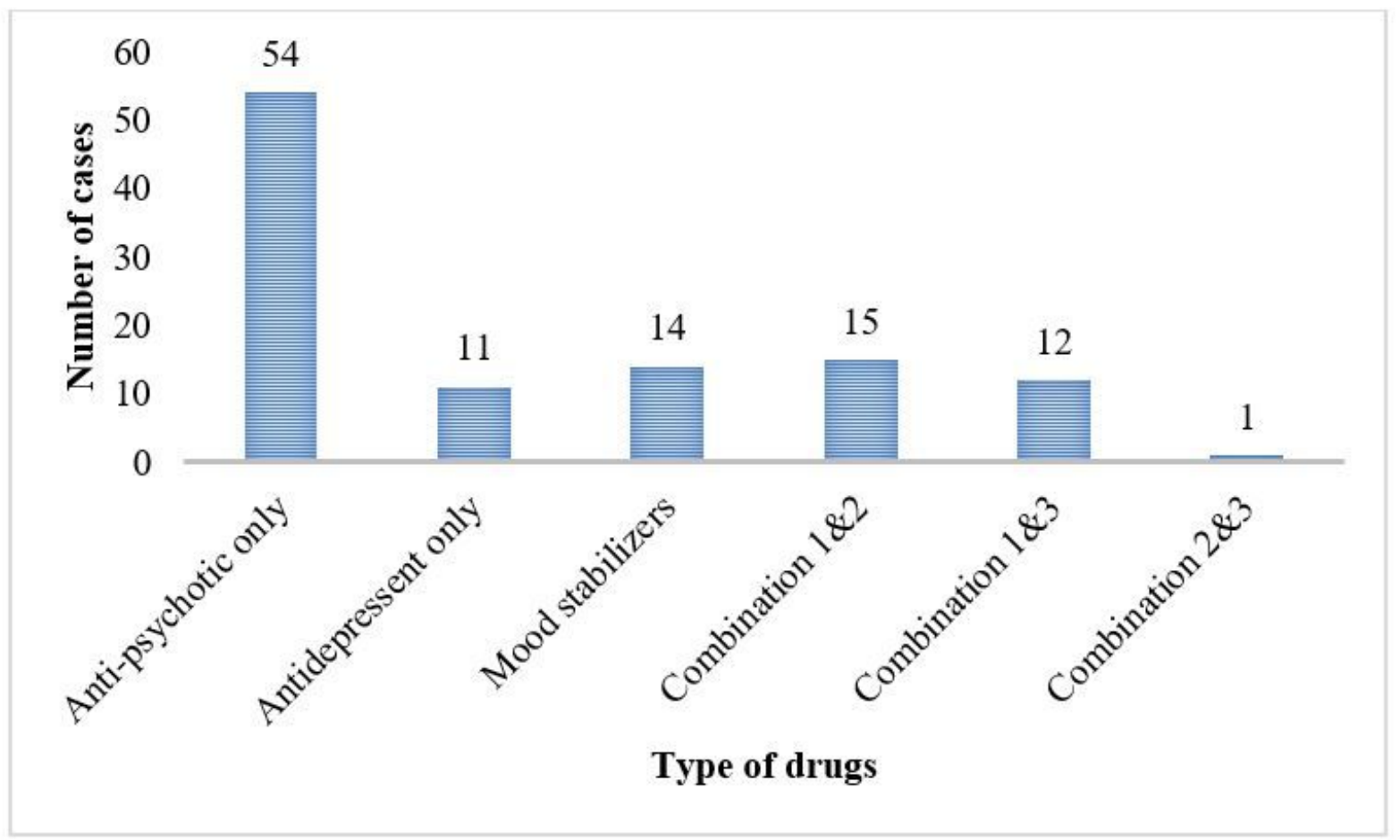

Figure 1

The proportion psychotropic drugs used by cases at Jimma Medical Center 